\begin{tabular}{|l|l|l|l|l|l|} 
J. Tek. Ling & Vol.11 & No.2 & Hal. 255 - 263 & Jakarta, Mei 2010 & ISSN 1441-318X \\
\hline
\end{tabular}

\title{
PENGARUH PEMBERIAN PAKAN ITIK DENGAN LIMBAH UDANG DAN LIMBAH KULIT KACANG KEDELAI YANG DIBERI PROBIOTIK TERHADAP PRODUKSI DAN WARNA KUNING TELUR
}

\author{
Sindu Akhadiarto \\ Peneliti di Pusat Teknologi Produksi Pertanian, TAB, \\ Badan Pengkajian dan Penerapan Teknologi
}

\begin{abstract}
The objective of this study was to utilize the superiority of agricultural waste in form of soybean hull and shrimp wastes and their combination on egg layer duck. This feed contains starbio probiotic functions for fiber digestion (soybean hull waste) and chitin (from shrimp waste). The expectation was that there would be duck ration which is able to increase egg production and quality and brighter reddish egg-yolk which is attractive and full of nutritions. The research was conducted in three stages. Stage I is Nutrient Digestional Value Test on the formula of soybean hull and shrimp wastes mixture on Duck Feed Contained Starbio." Stage II : experiment on "Mixture Formulation of soybean hull and shrimp wastes mixture on Duck Feed Contained Starbio Probiotik for Increasing The Performance of Egg Layer Duck" and III experiment on "The Production of Reddish Duck Egg-Yolk With Feed Contained soybean hull and Shrimp Wastes Mixture". The experiment concluded that : I) the provision of soybean hull and shrimp had significant effects on digestability of feed dried materials, but conversely had no effects on protein digestability and crude fiber, as well as on egg produktion and quality. There was no interaction between two materials in the treatment. 2) Shrimp waste tended to have effects on daily egg production of egg layer duck; 3) Yellow color of the eggs couldn't change to be reddish yet, since xanthophyl content had already lost in over-dried and already expired shrimp wastes.
\end{abstract}

Key Words : shrimp waste, soybean hull, probiotic, egg-yolk color

\section{PENDAHULUAN}

\subsection{Latar Belakang}

Di kalangan masyarakat pedesaan, ternak itik telah menyatu dengan kehidupan sehari-hari, hal ini secara tidak langsung berkaitan dengan sumber pakan di lapangan yang mampu dimanfaatkan oleh ternak itik. Beternak itik mempunyai potensi cukup besar untuk dikembangkan, dalam upaya meningkatkan pendapatan keluarga pedesaan. Selain produksinya cukup tinggi dan relatif tahan terhadap penyakit dibandingkan dengan unggas lainnya, cara pemeliharan itik juga cukup sederhana.

Itik Tegal tersebar di wilayah utara Jawa Tengah dan Jawa Barat, khususnya di wilayah pantai dan daerah persawahan. Bentuk badan itik Tegal termasuk bangsa Indian Runner, yaitu dengan posisi berdiri yang hampir tegak lurus dengan berat standar lebih kurang 1,5 kg1). Masa Produksi itik Tegal terjadi pada umur 1-2 tahun, dan masa produtif ini bisa berlangsung sampai tiga kali. Hasil telurnya dapat mencapai 250 butir per ekor/tahun dengan berat telur berkisar antara 60-70 gram per butir, dan 
warna kerabang kulit telurnya hijau kebirubiruan ${ }^{2)}$.

Telur itik adalah salah satu sumber protein yang cukup digemari di masyarakat, baik diolah menjadi telur asin, produk makanan seperti martabak, atau digoreng langsung bahkan ada yang digunakan sebagai jamu tradisional. Masalah yang sering terjadi di masyarakat adalah kuning telur dari itik-itik yang dipelihara secara intensif dengan pemberian pakan pabrikan menghasilkan warna kuning telur yang pucat, kurang menarik dan kurang disukai oleh konsumen. Itik-itik yang dipelihara secara tradisional dengan digembalakan di sawah, menghasilkan telur itik dengan warna kuning telur lebih merah. Namun masalahnya pada masa sekarang mencari lokasi untuk penggembalaan itik yang cukup luas dan bebas pestisida cukup sulit. Selain itu, itik yang dipelihara secara tradisional, produksi telurnya relative rendah, sehingga tidak menguntungkan peternak.

Untuk itu perlu dibuat suatu ransum dengan kandungan gizi yang cukup optimal, sehingga dapat memperbaiki performans itik petelur dan kualitas telur serta warna kuning telur ke arah merah cerah. Namun, untuk memperoleh susunan formula ransum yang sempurna, dibutuhkan penyediaan bahanbahan pakan bernilai gizi tinggi, padahal hingga saat ini ketersediannya masih terbatas dan masih tergantung dengan impor sehingga harganya mahal. Berdasarkan hal tersebut, maka penyusunan ransum harus diusahakan seoptimal mungkin degan tetap mengutamakan kualitas.

Tepung ikan dan bungkil kedelai merupakan sumber protein utama yang saat ini sering digunakan dalam peternakan unggas. Sayangnya, sebagian besar bahan pakan tersebut masih diipor. Hal ini disebabkan karena keterbatasan produksi dalam negeri dan persaingan dalam penggunaannya. Untuk itu perlu dicari bahan sumber protein baru yang memiliki kualitas dan kuantitas seperti tepung ikan atau bungkil kedelai. Salah satu pilihan sumber protein adalah tepung limbah udang.

Tepung limbah udang merupakan limbah industri pengolahan udang yang terdiri dari kepala dan kulit udang. Proporsi kepala dan kulit udang diperkirakan antara 30-40\% dari bobot udang segar. Faktor positif bagi tepung limbah udang adalah karena produk ini merupakan limbah, kesinambungan penyediaannya terjamin sehingga harganya akan cukup stabil dan kandungan nutrisinya pun bersaing dengan bahan baku lainnya. Dalam banyak hal ini lebih baik dibandingkan dengan tepung ikan yang bersifat musiman sehingga pada musim tertentu ikan sulit ditangkap dan harganya menjadi mahal. Kelemahan tepung limbah udang terletak pada kandungan asam amino paling kritis yang lebih rendah dibanding tepung ikan. Selain itu serat kasarnya relatif lebih tinggi, sebab diikut sertakannya kulit yang banyak mengandung khitin (faktor pembatas untuk tingkat penggunaan yang lebih tinggi dalam pakan ayam petelur). Melihat kemungkinan strategis dan harga yang cukup bersaing, sudah banyak dilakukan analisis mengenai kandungan nutrisi tepung limbah udang. Suatu penelitian juga telah dilakukan beberapa tahun lalu, untuk memastikan tingkat penggunaan yang optimum dalam pakan ayam dan itik petelur serta memperhitungkan kemampuan substitusi untuk mengurangi ketergantungan yang bersifat penuh pada tepung ikan impor. Titik perhatian terutama pada komposisi asam amino dan imbangan energi-protein. Analisis laboratorium memperlihatkan komposisi yang tidak jauh berbeda untuk serat kasar, lemak, protein kasar, kalsium, phospor dan kadar air. Hasil analisa Puslit Biologi-LIPI, menunjukkan bahwa kandungan protein limbah udang cukup tinggi yaitu protein $21,95 \%$; serat kasar $14,22 \%$; dan $\mathrm{Ca}$ 14,77 .

Penggunaan tepung limbah udang tidak mempengaruhi konsumsi pakan, score Haugh Unit dan tebal kerabang telur, karena kandungan nutrisi bahan pakan yang hampir sama ${ }^{(3)}$. Penggunaan tepung 
limbah udang juga dapat meningkatkan score warna kuning telur dan produksi telur dan produksi telur. Ini disebabkan karena tepung limbah udang mengandung zat warna astaxanthin yang mempengaruhi pigmentasi pada warna kuning telur. Secara keseluruhan tepung limbah udang dapat dipakai sebagai pengganti tepung ikan atau bungkil kedelai sampai batas tingkatan $12 \%{ }^{3}$.

Sedangkan pakan kulit dari beberapa jenis biji-bijian (kulit kacang kedelai, kulit gandum, cangkang coklat, dll.), adalah salah satu serat bermutu rendah yang dapat digunakan didalam penyusunan ransum unggas. Kulit biji-bijian ini berpotensi sebagai sumber energi, dan juga mempunyai keunggulan dalam menekan kadar kolesterol serta akumulasi pada tubuh ternak ${ }^{4}$. Disamping itu, serat dapat mengurangi absorpsi lemak, sehingga deposisi lemak dan kadar kolesterol produk dapat ditekan dan dapat meningkatkan retensi mineral Co dan $\mathrm{Fe}^{5}$.

Kulit kacang kedelai, merupakan bahan pakan alternatif yang mempunyai potensi sangat besar, baik sebagai sumber energi, sumber serat kasar, maupun sumber makro nutrient lainnya ${ }^{6)}$. Faktor pembatas penggunaan kulit kacang kedelai dalam ransum adalah tingginya kandungan serat kasar dari limbah tersebut, karena ternak unggas (itik) tidak dapat mencerna serat kasar. Akan tetapi kehadiran serat kasar dalam ransum esensial sekali, karena serat kasar ternyata mempunyai fungsi fisiologis dan fungsi nutrisi bagi ternak unggas ${ }^{7}$. Hasil analisa proksimat Laboratorium Teknologi Pakan Ternak, kandungan nutrient kulit kacang kedelai adalah : untuk kadar air $75,3 \%$, Protein 9,3\%, lemak 6,4\%. Disamping itu penggunaan bahan pakan yang berasal dari hijauan berupa kulit kacang kedelai ini sebagai sumber vitamin juga sebagai sumber Xanthophyl.

Upaya untuk meningkatkan nilai nutrisi dari kulit biji-bijian tersebut (kulit kacang kedelai) dapat dilakukan dengan memanfaatkan kemampuan dari probiotik. Salah satu nama produk yang dijual dipasaran adalah Starbio. Starbio berbentuk bubuk coklat yang terdiri dari multi mikroorganisme. Probiotik merupakan bahan yang berasal dari kultur kuman atau substansi lain yang dapat mempengaruhi keseimbangan alami dalam usus dan bila diberikan dalam jumlah yang tepat dapat meningkatkan efisiensi penyerapan zatzat makanan ${ }^{8}$. Dilaporkan juga bahwa hasil analisa proksimat probiotik starbio mengandung : $19,17 \%$ air, 10,42\% protein, $0,11 \%$ lemak kasar, $8,37 \%$ serat kasar, dan $51,54 \%$ abu $^{9}$.

Beberapa hasil penelitian mengenai penggunaan probiotik dalam ransum unggas, ternyata mampu meningkatkan penampilan, nilai guna pakan serat, dan menurunkan perlemakan karkas unggas. Hasil penelitian menunjukkan bahwa penggunaan probiotik dalam ransum ternyata dapat menurunkan kandungan kolesterol telur ${ }^{10}$. Manfaat probiotik lainnya pada unggas antara lain meningkatkan aktivitas enzim pencernaan dan menurunkan aktivitas enzim bakteri yang merugikan, memperbaiki pencernaan, serta merangsang sistem kekebalan tubuh unggas ${ }^{11)}$.

\subsection{Tujuan Penelitian}

Penelitian ini bertujuan untuk memanfaatkan limbah udang dan limbah kulit kacang kedelai pada pakan itik petelur dengan memberi pakan imbuhan probiotik starbio. Harapannya akan dihasilkan produk pakan itik yang mampu meningkatkan produksi dan kualitas telur serta diperoleh warna kuning telur kearah merah cerah yang berharga lebih tinggi.

\section{MATERI DAN METODE}

Penelitian dilaksanakan di daerah peternakan itik Parung Panjang, Bogor. Lama penelitian delapan minggu, dengan terlebih dahulu diadaptasikan selama seminggu. Waktu penelitian mulai Nopember 2008 sampai dengan Januari 2009. 
Dalam penelitian ini digunakan sebanyak 135 ekor itik Tegal, umur 23 minggu. Untuk uji kecernaan dan data endogenous diperlukan itik grower (23 minggu) sebanyak 17 ekor. Sistem pemberian pakan secara terbatas sesuai dengan kebutuhan itik.

Kulit kacang kedelai diperoleh dari petani di daerah Bogor yang merupakan limbah dari pengambilan biji kedelai. Kepala udang diperoleh dari perusahaan swasta di daerah Tanjung Priok, Jakarta, yang bergerak dibidang ekspor udang beku.

Ransum yang diberikan adalah ransum untuk itik layer berbentuk pellet guna mengurangi jumlah pakan yang tumpah dan dapat memperoleh total konsumsi yang lebih akurat. Pakan itik layer mengandung Protein Kasar $(P K)=19 \%$ dan Energi Metabolis (EM) $=2.850 \mathrm{kkal} / \mathrm{kg}$, dengan komposisi kandungan limbah udang dan limbah kulit kedelai sebanyak sesuai perlakuan. Limbah udang berupa kepala udang dan kulit udang dibuat tepung, demikian juga kulit kacang kedelai dibuat tepung terlebih dahulu. Kemudian diproses menjadi pakan jadi bentuk pellet, dan dilakukan analisis proksimat ${ }^{12)}$ antara lain kadar air, protein kasar, lemak kasar dan vit A. Ransum disusun dengan Metoda Uji Coba dengan menggunakan Program FeedStaR, yang programnya sudah dibuat oleh Bidang Teknologi Perikanan dan Peternakan, BPPT dalam bahasa Indonesia.
Penelitian ini dilaksanakan melalui tiga tahap Perlakuan. Perlakuan I adalah "uji nilai cerna nutrien pakan. Perlakuan II adalah "untuk mengetahui performans itik petelur (produksi telur)" dan perlakuan III adalah "untuk mengetahui warna kuning telur". Data yang diperoleh diolah secara statistik dengan mengunakan analisis keragaman rancangan acak lengkap $(\mathrm{RAL})^{13)}$.

\section{HASIL DAN PEMBAHASAN}

\subsection{Nilai Cerna Nutrien Pakan}

Dari hasil penelitian menunjukkan bahwa pemberian kulit kacang kedelai dan kepala udang berpengaruh nyata terhadap kecernaan bahan kering (BK) dan terdapat interaksi (Tabel 1). Penggunaan limbah udang sampai $12 \%$ dengan tanpa pemberian kulit kacang kedelai memberikan kecernaan BK yang bagus. Demikian juga penggunaan kulit kacang kedelai dapat digunakan sampai $10 \%$ dalam pakan itik namun tanpa diberikan limbah udang. Penggunaan kedua bahan tersebut akan menurunkan kecernaan BK pakan. Hal ini menunjukkan bahwa dalam menyusun ransum itik sebaiknya menggunakan salah satu bahan kulit kacang kedelai atau limbah udang agar penyerapan nutrien lebih optimal.

Tabel 1. Kecernaan Bahan Kering (BK).

\begin{tabular}{|c|c|c|c|c|c|}
\hline \multicolumn{2}{|c|}{ Perlakuan } & \multicolumn{2}{|c|}{ Ulangan } & \multirow[b]{2}{*}{ Total } & \multirow[b]{2}{*}{ Rata-rata } \\
\hline Limbah Kedelai & Limbah Udang & 1 & 2 & & \\
\hline \multicolumn{6}{|c|}{$\%$} \\
\hline \multirow[t]{3}{*}{0} & 0 & 84,98 & 85,36 & 170,34 & $85,17^{a}$ \\
\hline & 6 & 83,09 & 83,47 & 166,56 & $83,28^{c}$ \\
\hline & 12 & 83,62 & 83,26 & 166,88 & $83,44^{\mathrm{ab}}$ \\
\hline \multirow[t]{3}{*}{5} & 0 & 81,23 & 81,71 & 162,94 & $81,47^{\text {cde }}$ \\
\hline & 6 & 79,86 & 79,94 & 159,80 & $79,90^{\mathrm{gh}}$ \\
\hline & 12 & 80,39 & 80,41 & 160,80 & $80,40^{\text {efg }}$ \\
\hline \multirow[t]{3}{*}{10} & 0 & 81,98 & 83,24 & 165,22 & $82,61^{\mathrm{cd}}$ \\
\hline & 6 & 80,01 & 81,47 & 161,48 & $80,74^{\text {def }}$ \\
\hline & 12 & 78,11 & 78,55 & 156,66 & $78,33^{\mathrm{h}}$ \\
\hline & \multicolumn{3}{|l|}{ Total } & $1.470,68$ & 81,70 \\
\hline
\end{tabular}


Tabel 2. Kecernaan Protein Kasar (PK)

\begin{tabular}{|c|c|c|c|c|c|}
\hline \multicolumn{2}{|c|}{ Perlakuan } & \multicolumn{2}{|c|}{ Ulangan } & \multirow[b]{2}{*}{ Total } & \multirow[b]{2}{*}{ Rata-rata } \\
\hline Limbah Kedelai & Limbah Udang & 1 & 2 & & \\
\hline \multicolumn{6}{|c|}{$\%$} \\
\hline \multirow[t]{3}{*}{0} & 0 & 20,68 & 20,69 & 41,37 & 20,68 \\
\hline & 6 & 20,63 & 20,62 & 41,25 & 20,63 \\
\hline & 12 & 20,55 & 20,54 & 41,09 & 20,55 \\
\hline \multirow[t]{3}{*}{5} & 0 & 20,24 & 20,27 & 40,51 & 20,26 \\
\hline & 6 & 19,97 & 19,96 & 39,93 & 19,97 \\
\hline & 12 & 19,82 & 19,80 & 39,62 & 19,81 \\
\hline \multirow[t]{4}{*}{10} & 0 & 19,95 & 19,95 & 39,90 & 19,95 \\
\hline & 6 & 19,56 & 19,60 & 39,16 & 19,58 \\
\hline & 12 & 19,35 & 19,34 & 38,69 & 19,35 \\
\hline & Total & 180,75 & 180,76 & 361,51 & $20,08^{\text {tb }}$ \\
\hline
\end{tabular}

Tabel 3. Kecernaan Serat Kasar (SK)

\begin{tabular}{|c|c|c|c|c|c|}
\hline \multicolumn{2}{|c|}{ Perlakuan } & \multicolumn{2}{|c|}{ Ulangan } & \multirow[b]{2}{*}{ Total } & \multirow[b]{2}{*}{ Rata-rata } \\
\hline Limbah Kedelai & Limbah Udang & 1 & 2 & & \\
\hline \multicolumn{6}{|l|}{ 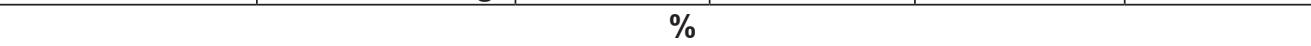 } \\
\hline \multirow[t]{3}{*}{0} & 0 & 7,97 & 7,96 & 15,93 & 7,97 \\
\hline & 6 & 8,66 & 8,66 & 17,32 & 8,66 \\
\hline & 12 & 9,49 & 9,48 & 18,98 & 9,49 \\
\hline \multirow[t]{3}{*}{5} & 0 & 8,26 & 8,27 & 16,54 & 8,27 \\
\hline & 6 & 8,64 & 8,58 & 17,22 & 8,61 \\
\hline & 12 & 9,79 & 9,77 & 19,56 & 9,78 \\
\hline \multirow[t]{4}{*}{10} & 0 & 8,92 & 8,94 & 17,86 & 8,93 \\
\hline & 6 & 9,09 & 9,06 & 18,15 & 9,08 \\
\hline & 12 & 9,97 & 9,95 & 19,92 & 9,96 \\
\hline & Total & 80,80 & 80,68 & 161,48 & $8,97^{\text {tb }}$ \\
\hline
\end{tabular}

\subsection{Produksi Telur}

Pemberian ransum dilakukan secara terbatas sesuai dengan kebutuhan, yaitu 150 g/ekor/hari. Hal ini didasarkan dari hasil penelitian, yang menyatakan bahwa konsumsi itik lokal berkisar antara $125 \mathrm{~g} /$ ekor/ hari sampai dengan 168 g/ekor/hari, tergantung dari jenis itiknya ${ }^{15)}$. Pemberian ransum itik perlu dikontrol karena sifat itik yang cenderung mengkonsumsi ransum berapapun yang diberikan, sehingga jika terjadi kegemukan dikawatirkan awal produksi telur akan mengalami gangguan.

Pemberian ransum yang terukur dan terkontrol ini, berakibat jumlah energi dan protein yang dikonsumsi per hari untuk masing-masing itik menjadi sama. Hal ini dikarenakan semua ransum yang diberikan selalu habis, sedangkan konsumsi energi diperoleh dari konsumsi Bahan Kering (BK) yang dikonsumsi dikalikan kandungan energi pakan, demikian juga untuk protein, dikalikan dengan kandungan protein pakan.

Rata-rata produksi telur harian $(\mathrm{PTH})$ tidak menunjukkan perbedaan yang nyata untuk setiap minggunya (Tabel 4). Dilihat dari PTH yang diamati selama tujuh minggu tampak perlakuan kulit kacang kedelai $0 \%$, limbah udang 12\% (K0-U12), kulit kacang kedelai 5\% limbah udang 12\% (K5-U12) dan perlakuan kulit kacang kedelai $10 \%$ udang 12\% (K10-U12), kecenderungannya menghasilkan produksi harian yang lebih baik, namun secara nyata perbedaan itu belum tampak. Untuk itu perlu dilakukan uji 
Tabel 4. Rata-rata Produksi Telur selama Tujuh Minggu.

\begin{tabular}{|c|c|c|c|c|c|c|c|c|c|}
\hline \multicolumn{2}{|c|}{ Perlakuan } & \multicolumn{8}{|c|}{ Minggu ke : } \\
\hline $\begin{array}{l}\text { Limbah } \\
\text { Kedelai }\end{array}$ & $\begin{array}{l}\text { Limbah } \\
\text { Udang }\end{array}$ & 1 & 2 & 3 & 4 & 5 & 6 & 7 & $\begin{array}{l}\text { Rata- } \\
\text { rata }\end{array}$ \\
\hline \multicolumn{10}{|c|}{ 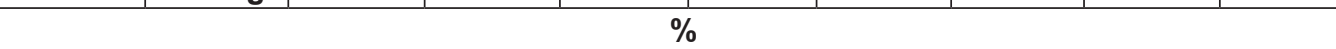 } \\
\hline \multirow[t]{3}{*}{0} & 0 & 19,05 & 27,80 & 26,14 & 14,67 & 14,76 & 19,52 & 19,05 & $20,14^{a}$ \\
\hline & 6 & 16,67 & 33,33 & 35,71 & 40,48 & 16,67 & 38,10 & 45,24 & $32,31^{a}$ \\
\hline & 12 & 30,85 & 19,05 & 21,43 & 47,62 & 30,09 & 66,67 & 31,23 & $35,28^{a}$ \\
\hline \multirow[t]{3}{*}{5} & 0 & 19,05 & 19,05 & 19,05 & 30,95 & 16,67 & 35,71 & 23,81 & $23,47^{a}$ \\
\hline & 6 & 26,19 & 30,95 & 35,71 & 28,57 & 19,05 & 26,19 & 09,53 & $25,17^{a}$ \\
\hline & 12 & 38,10 & 71,43 & 73,81 & 35,61 & 35,71 & 45,24 & 30,95 & $47,26^{a}$ \\
\hline \multirow[t]{3}{*}{10} & 0 & 47,62 & 23,81 & 19,05 & 30,95 & 28,57 & 30,95 & 22,38 & $29,05^{a}$ \\
\hline & 6 & 42,86 & 16,67 & 14,29 & 16,67 & 23,81 & 23,81 & 14,29 & $21,77^{a}$ \\
\hline & 12 & 40,47 & 21,43 & 23,81 & 42,86 & 26,19 & 42,86 & 42,86 & $34,35^{a}$ \\
\hline
\end{tabular}

Keterangan : ${ }^{\text {}}$.superskrip yang sama pada lajur yang sama menunjukkan tidak berbeda nyata $(\mathrm{P}>0,05)$.

coba lebih lanjut menggunakan udang segar dan dosis yang lebih besar untuk mengetahui pengaruhnya terhadap produksi yang lebih nyata.

Tidak nampaknya adanya interaksi antara bahan kulit kacang kedelai dengan limbah udang, menunjukkan bahwa kandungan vitamin pada kulit kedelai tidak berperan dalam mendukung kualitas telur. Jadi PTH cenderung lebih dipengaruhi oleh limbah udang. Dinyatakan bahwa kandungan nutrien limbah udang untuk kadar air 10,32\% adalah : Protein 14,34\%, Energi Bruto 3.577 $\mathrm{kkal} / \mathrm{kg}$, lemak $6,62 \%$, serat kasar $17,59 \%$, Ca $7,76 \%, P 1,31 \%$, methionin $1,26 \%$ dan Lysin 3,11\% ${ }^{16)}$. Dinyatakan lebih lanjut bahwa penggunaan limbah udang tidak berpengaruh pada konsumsi pakan, skor Haugh Unit (HU) dan tebal kerabang telur, namun akan meningkatkan produksi telur dan warna kuning telur.

\subsection{Warna Kuning Telur}

Dalam penelitian ini pengaruh penggunan limbah kulit kacang kedelai dan Limbah udang tidak menunjukkan perbedaan yang nyata terhadap berat telur, berat kerabang dan tebal kerabang serta Haugh Unit (HU) telur itik.
Berat telur di semua perlakuan masih dibawah rata-rata berat telur itik yaitu berkisar antara 61,9 gram sampai 72,8 gram. Menurut hasil penelitian bahwa berat telur itik yang mempunyai daya tetas tinggi adalah 75-84 gram $^{18)}$. Hal ini dikarenakan telur yang dihasilkan masih pada awal produksi yaitu umur 21 minggu yang diambil datanya selama 4 minggu. Umumnya semakin lama masa produksi, ukuran telur akan semakin menjadi besar.

Faktor yang menentukan pembentukan kerabang adalah kalsium karena sebagian besar kerabang terdiri dari kalsium karbonat $(94,0 \%)$ sehingga kelebihan kalsium sering mengakibatkan penimbunan kalsium pada kerabang ${ }^{18)}$. Dalam penelitian ini penggunan kepala udang sampai $12 \%$ belum menunjukkan tanda kelebihan kalsium. Hal ini ditunjukkan dengan tidak bertambah tebal dan berat dari kerabang itik petelur yang diberi pakan perlakuan. Untuk itu penambahan sumber kalsium baik berupa penambahan dosis kepala udang maupun sumber kalsium lain seperti tepung tulang masih dimungkinkan untuk menambah ketebalan dan berat kerabang telur.

Dari hasil penelitian ini menunjukkan bahwa hasil Haugh Unit (HU) yang bagus yaitu diatas $98 \%{ }^{19)}$, kualitas telur dapat diketahui 
dari indeks telur, yaitu perbandingan lebar maksimal dan panjang telur dikalikan dengan 100. Semakin tinggi indek telur semakin baik digunakan sebagai telur tetas. Tingginnya nilai HU yang dihasilkan dimungkinkan bukan karena pengaruh perlakuan tetapi karena kondisi telur saat pengukuran yang sumber serat kasar dan protein. Hasil analisa proksimat laboratorium Teknologi Pakan Ternak, kandungan nutrien kulit kacang kedelai untuk kadar air $75,3 \%$, Protein $9,3 \%$, lemak $6,4 \%$ dan serat kasar $31,6 \%$. Kandungan gizi kulit kedelai ini mendekati kandungan gizi hijauan pakan ternak.

Tabel 6. Data Kualitas Telur Itik.

\begin{tabular}{|l|l|l|l|l|l|l|}
\hline \multicolumn{6}{|c|}{ Perlakuan } & \multicolumn{5}{c|}{ Variabel Pengamatan : } \\
\hline $\begin{array}{l}\text { Kimbah } \\
\text { Kedelai }\end{array}$ & $\begin{array}{l}\text { Limbah } \\
\text { Udang }\end{array}$ & $\begin{array}{c}\text { Berat Telur } \\
(\mathrm{grm})\end{array}$ & $\begin{array}{c}\text { Berat Kerabang } \\
(\mathrm{mg})\end{array}$ & $\begin{array}{c}\text { Tebal Kerabang } \\
(\mathrm{mm})\end{array}$ & Haugh Unit & $\begin{array}{c}\text { Warna Kuning } \\
\text { Telur }\end{array}$ \\
\hline 0 & 0 & 63,13 & 10,20 & 0,14 & 99,01 & ++ \\
\hline & 6 & 63,66 & 10,29 & 0,21 & 99,01 & ++ \\
\hline & 12 & 69,16 & 11,33 & 0,14 & 98,94 & ++ \\
\hline 5 & 0 & 72,80 & 12,20 & 0,10 & 98,91 & ++ \\
\hline & 6 & 64,36 & 11,25 & 0,22 & 99,01 & ++ \\
\hline 10 & 12 & 64,70 & 09,20 & 0,12 & 98,99 & ++ \\
\hline & 0 & 66,25 & 11,25 & 0,13 & 98.97 & ++ \\
\hline & 6 & 66,87 & 11,29 & 0,21 & 98,89 & ++ \\
\hline
\end{tabular}

Keterangan : ++ skor warna kuning telur 9 (standard), skor paling tinggi adalah 14 .

masih baru dan keadaan segar, sehingga telur masih dalam keadaan kental.

Penggunaan limbah udang belum dapat meningkatkan skor warna kuning telur dan produksi telur. Ini disebabkan karena tepung limbah udang mengandung zat warna astaxantin yang dapat mempengaruhi pigmentasi pada warna kuning telur ${ }^{3}$. Namun dari hasil penelitian disini menunjukkan bahwa penggunaan limbah udang dalam hal ini kepala udang tidak meningkatkan skor kuning telur, hal ini dimungkinkan bahwa limbah udang yang digunakan sudah dalam bentuk kering dan telah disimpan terlalu lama sehingga kandungan astaxanthinnya sudah hilang. Dinyatakan pula bahwa astaxanthin merupakan senyawa tidak stabil dan dapat hilang dari bahan pakan unggas karena oksidasi ${ }^{20)}$.

Peran kulit kacang kedelai sebagai sumber vitamin A yang merupakan permbentuk xanthophyl, juga belum kelihatan dalam meningkatkan warna kuning telur. $\mathrm{Hal}$ ini dimungkinkan kondisi kulit kacang kedelai yang kering sehingga perannya lebih kearah

\section{KESIMPULAN DAN SARAN}

Dari hasil penelitian terhadap pengaruh pemberian limbah kulit kacang kedelai dan limbah udang pada pakan yang ditambah probiotik Starbio, maka diperoleh hasil sebagai berikut :

- Pemberian limbah udang dan limbah kulit kacang kedelai pada pakan yang ditambah probiotik Starbio berpengaruh terhadap kecernaan bahan kering pakan, namun tidak berpengaruh terhadap kecernaan protein kasar (PK) dan serat kasar (SK) serta terhadap produksi dan kualitas telur.

- Perlakuan kedua bahan tersebut juga tidak ada interaksi. Limbah udang cenderung lebih berpengaruh terhadap produksi telur harian (PTH) itik petelur.

- Pemberian limbah kulit kedelai sampai $10 \%$ dan limbah udang $12 \%$ pada pakan tidak berpengaruh 
nyata terhadap produksi telur dan warna kuning telur, sehingga secara ekonomis bisa diterapkan untuk menekan harga pakan supaya lebih murah.

- Warna kuning telur yang dihasilkan masih belum berwarna merah, hal ini dikarenakan limbah udang yang dipakai sudah kering dan disimpan terlalu lama, sehingga kandungan astaxanthin nya sudah banyak yang hilang.

Perlu dilakukan penelitian lanjutan dengan pemberian limbah udang yang masih segar dengan dosis lebih besar untuk mengetahui pengaruhnya lebih nyata.

\section{DAFTAR PUSTAKA}

1. Srigandono. 1997. Produksi Unggas Air. Gadjah Mada University Press. Yogyakarta

2. Windhyarti, S. S. 1999. Beternak Itik Tanpa Air. Penebar Swadaya, Jakarta.

3. Poultry Indonesia. 2008. Limbah Udang Pengganti Tepung Ikan. www. poultryindonesia.com.

4. Piliang, W.G. and W. Manalu. 1988. Effect of different levels of, zinc supplementation in rice bran diets onzinc status and on the performance of laying hens. Procs. Sem. Nas. Peternak dan Forum Peternak Unggas dan Aneka Ternak II. hal. 125-134. Balai Penelitian Ternak, Bogor.

5. Basyir, A.K. 1999. Serat Kasar dan Pengaruhnya pada Broiler. Poultry Indonesia. Okt. 1999, No.233, Hal. : 43-45.

6. Bidura, IGNG., NLG. Sumardani, T. Istri Putri dan IBG. Partama, 2005. Pengaruh Pemberian Ransum Terfermentasi terhadap Pertambahan Bobot Badan, Karkas dan Jumlah Lemak Abdomen pada Itik Bali. J. Pengembangan Peternakan Tropis,
Vol. 33 (4) : 274-285.

7. Siri, S.,H.Tobioka and I. Tasaki, 1992. Effects of Dietary Cellulose and Feed Intake on Energy Utilization in Chickens. AJAS 5 (4) : 741-746.

8. Andajani, R., 1997. Peran Probiotik dalam Meningkatkan Produksi. Dalam: Poultry Indonesia No. 206. Jakarta

9. Sartita, T., Y.C. Rahardjo dan K. Dwiyanto, 1994. Penggunaan Probiotik Starbio dalam Ransum dengan Tingkat Protein yang Berbeda terhadap Penampilan Kelinci Lepas Sapih. Balitnak, Bogor.

10. Abdulrahim, S.M., M.S.Y. Haddadin, E.A.R. Haslamoun and R.K. Robinson, 1996. The Influences of Lactobacillus and Bacitracin on Layer Performance of Chickens and Cholesterol Content of Plasma and Egg Yolk. British Poultry Sci. 37 : 341-346.

11. Jin, L.Z., Y.W. Ho, N. Abdullah and S. Jalaludin, 1997. Probiotic in Poultry : Modes of Action. Worlds Poultry Sci. J. 53(4) : 351-368.

12. AOAC. 1984. Official methods of analysis. $12^{\text {th }}$. Ed. Association of Official analytical chemist Washington DC.

13. Steel, R.G.D and JH. Torrie, 1993. Prinsip dan Prosedur Statistika. Terjemahan Bambang Sumantri, Cetakan Kedua. PT. Gramedia Pustaka Utama, Jakarta

14. Mangisah, I., N. Suthama dan H.I. Wahyuni, 2009. Pengaruh Penambahan Starbio dalam Ransum Berserat Kasar Tinggi terhadap Performan Itik. Fapet Undip. Seminar Nasional Kebangkitan Peternakan, 20 Mei 2009. Semarang.

15. Yuwanto, T. and A. Wibowo. 1997. The Effect of Feeding Intervals and Sex Ratio on Production and Reproduction of Tegal Native Ducks. $11^{\text {th }}$ European Symposium on Waterfowl. Nantes (France). September 8-10.1997

17. Marganof (2003). Potensi Limbah Udang sebagai Penyerap Logam Berat 
(Timbal, Kadmium dan Tembaga) di Perairan. http://rudvct.topcities.com/ pps702 71034/marganof.htm

18. Changkang, W., A. Li and Guanggying Wang. 1999. Effect of the quantitative characters of hachability in musscovy duck. Proceedings $1^{\text {st }}$ World Water Fowl Conference. Taiwan. R.O.C. December 1-4.1999.
19. Wahyu, J. 1997. Ilmu Nutrisi Unggas. Gadjah Mada University Press. Yogyakarta.

20. Etches, R.. 1996. Reproduction in Poultry. Department of Animal and Poultry Science University of Guelph. Ontario. Kanada.

21. Anggorodi, H. R. 1995. Nutrisi Aneka Ternak Unggas. PT Gramedia Pustaka Utama. Jakarta 